\title{
Splenic artery embolization: An alternative approach in a critically ill patient with autoimmune hemolytic anemia
}

\author{
Splenik arter embolizasyonu: Otoimmün hemolitik anemili kritik \\ derecede ağır bir hastada yaklaşım seçeneği
}

\author{
Mine Durusu Tanrı̈ver ${ }^{1}$, Bora Peynircioğlu², Begüm Ergan Arsava ${ }^{3}$, Arzu Topeli İskit ${ }^{4}$ \\ ${ }^{1}$ Department of Internal Medicine, General Internal Medicine Section, Faculty of Medicine, Hacettepe University, \\ Ankara, Turkey \\ ${ }^{2}$ Department of Radiology, Faculty of Medicine, Hacettepe University, Ankara, Turkey \\ ${ }^{3}$ Department of Pulmonology, Faculty of Medicine, Hacettepe University, Ankara, Turkey \\ ${ }^{4}$ Department of Internal Medicine, General Internal Medicine Section and Medical Intensive Care Unit, Faculty \\ of Medicine, Hacettepe University, Ankara, Turkey
}

\begin{abstract}
Assessment of general health status and hematological parameters usually precedes the use of invasive diagnostic and therapeutic procedures in critically ill patients. Angiography can be effective and safe as a substitute for major surgical procedures, or as a bridging therapy in such cases. We present a critically ill patient with hemolytic anemia that underwent splenic artery embolization as a bridging therapy. We aimed to emphasize that minimally invasive approaches and multidisciplinary care can be utilized in the treatment of critically ill patients with accompanying hematological disease.
\end{abstract}

(Turk J Hematol 2011; 28: 135-8)

Key words: Critical care medicine, therapeutic embolization, hemolytic anemia

Received: December 14, 2009

Accepted: April 22, 2010

\section{Özet}

Kritik derecede ağır bir hastanın genel durum bozukluğu ve hematolojik parametreleri, invazif tanı ve tedavi girişimlerinin uygulanmasına izin vermeyebilir. Bu tür olgularda, anjiyografik yaklaşımlar büyük cerrahi girişimlerin yerini tutacak veya köprü tedavisi görevi görecek güvenilir ve etkili bir tedavi yöntemi olabilir. Burada, köprü tedavisi olarak dalak arteri embolizasyonu yapılan hemolitik anemili kritik durumda ağır bir hasta sunulmaktadır. Bu olgu, ciddi bir kan hastalığının eşlik ettiği bu tür hastalarda multidisipliner bakımın önemini ve daha az invazif yaklaşımların seçilmesinin uygun olabileceğini vurgulamaktadır. (Turk J Hematol 2011; 28: 135-8)

Anahtar kelimeler: Kritik hasta tıbbı, terapötik embolizasyon, hemolitik anemi

Geliş tarihi: 14 Aralık 2009

Kabul tarihi: 22 Nisan 2010

Address for Correspondence: M.D. Mine Durusu Tanriöver, Department of Internal Medicine, General Internal Medicine Section, Faculty of Medicine, Hacettepe University, Ankara, Turkey Phone: +90312 3053029 E-mail: mdurusu@hacettepe.edu.tr 


\section{Introduction}

Autoimmune hemolytic anemia is a disorder in which immunoglobulin (Ig) G-coated erythrocytes are sequestered and destroyed in the spleen. Splenectomy can result in partial remission in patients refractory to medical therapy. Invasive procedures, especially major surgery, usually cannot be performed in critically ill patients because of the tendency for bleeding, labile hemodynamic state, and poor general health status. Angiography can be an effective and safe therapeutic modality in such cases.

\section{Case Report}

A 70-year-old male patient presented to the hematology outpatient clinic with jaundice and dark urine, which were present for 1 month. His hemoglobin was $8.5 \mathrm{~g} \mathrm{dL}^{-1}$ at presentation (Table 1). Anisocytosis and poikilocytosis were evident based on peripheral smear. The patient was diagnosed with autoimmune hemolytic anemia, and Deltacortril $^{\circledR}$ (Pfizer, Istanbul, Turkey) $5 \mathrm{mg} \mathrm{d}^{-1}$ p.o. and Folbiol ${ }^{\circledR}$ (IE Ulagay, Istanbul, Turkey) $5 \mathrm{mg} \mathrm{d}^{-1}$ p.o. were started. One month later the patient's hemoglobin level was $6.8 \mathrm{~g} \mathrm{dL}^{-1}$ (Table). He was admitted to the emergency department and after his hemoglobin dropped to $3.8 \mathrm{~g} \mathrm{dL}^{-1}$ he was transferred to the medical intensive care unit (ICU).

Upon admission to the ICU the patient's arterial blood pressure was 125/55 mmHg and pulse was

Table 1. The patient's laboratory findings

\begin{tabular}{lccc}
\hline & $\begin{array}{c}\text { Normal } \\
\text { range }\end{array}$ & $\begin{array}{c}\text { At the time } \\
\text { of diagnosis }\end{array}$ & $\begin{array}{c}\text { At the time } \\
\text { of admission } \\
\text { 1 month after } \\
\text { diagnosis }\end{array}$ \\
\hline Hemoglobin & $14-16 \mathrm{~g} \mathrm{dL}^{-1}$ & $8.5 \mathrm{~g} \mathrm{dL}^{-1}$ & $6.8 \mathrm{~g} \mathrm{dL}^{-1}$ \\
\hline MCV & $80.7-95.5 \mathrm{fL}$ & $97.7 \mathrm{fL}$ & $100.8 \mathrm{fL}$ \\
\hline RDW & $11.8 \%-14.3 \%$ & $14.5 \%$ & $16.5 \%$ \\
\hline Reticulocyte count & $0.6 \%-2.6 \%$ & $7.3 \%$ & \\
\hline $\begin{array}{l}\text { Serum total } \\
\text { bilirubin }\end{array}$ & $0.1-1.2 \mathrm{mg} \mathrm{dL}^{-1}$ & $3.41 \mathrm{mg} \mathrm{dL}-1$ & 13.18 \\
\hline Serum indirect & $0-1.2 \mathrm{mg} \mathrm{dL}^{-1}$ & & $12.31 \mathrm{mg} \mathrm{dL}^{-1}$ \\
bilirubin & & & \\
\hline Serum LDH & $240-480 \mathrm{U} \mathrm{L}^{-1}$ & $496 \mathrm{U} \mathrm{L}^{-1}$ & $521 \mathrm{U} \mathrm{L}^{-1}$ \\
\hline Haptoglobin & $36-195 \mathrm{mg} \mathrm{dL}^{-1}$ & $<5.83 \mathrm{mg} \mathrm{dL}^{-1}$ & \\
\hline
\end{tabular}

MCV: Mean corpuscular volume; RDW: red cell distribution width; LDH: lactate dehydrogenase
$106 \mathrm{bpm}$. Jaundice was evident. The liver was 16 $\mathrm{cm}$ long and there was dullness to percussion over Traube's space. Transfusion could not be performed because the patient's serum reacted with all erythrocyte suspensions tested. He received intravenous Prednol-L ${ }^{\circledR}$ (Mustafa Nevzat, Istanbul, Turkey) $1 \mathrm{~g} \mathrm{~d}^{-1}$ for $3 \mathrm{~d}$ and IG-Vena $\mathrm{N}^{\circledR}$ (Biosano Laboratorio, Santiago, Chile) $1 \mathrm{~g} \cdot \mathrm{kg} \cdot \mathrm{d}^{-1}$ for $2 \mathrm{~d}$. The patient underwent 2 cycles of plasmapheresis. Immunosuppressive therapy was continued with Prednol-L ${ }^{\circledR}$ (Mustafa Nevzat) $1 \mathrm{mg} \cdot \mathrm{kg} \cdot \mathrm{d}^{-1}$ and Sandimmun Neoral ${ }^{\circledR}$ (Novartis Pharma A.G., Basel, Switzerland) $100 \mathrm{mg}$ p.o. b.i.d. Rituximab was considered as an alternative for the treatment of refractory hemolytic anemia; however, the drug could not be immediately obtained. The patient was referred to the surgery department for splenectomy, but as the surgeons required a hemoglobin level $>9 \mathrm{~g} \mathrm{dL}^{-1}$ and a compatible erythrocyte suspension could not be found, the patient did not undergo surgery. The patient was then referred to the interventional radiology department for splenic artery embolization.

The patient's hemodynamic parameters were normal just before catheterization: blood pressure was 133/63 mmHg, pulse rate was $82 \mathrm{bpm}$, body temperature was $36.1^{\circ} \mathrm{C}$, and pulse oximeter oxygen saturation was $99 \%$ while the patient breathed through a nasal oxygen cannula. On the $8^{\text {th }}$ day in the ICU selective splenic artery injection was performed via the left main femoral artery via celiac artery catheterization. After mapping the splenic artery branches, the post hilar branches of the splenic artery were catheterized superselectively using a microcatheter. Approximately $75 \%$ of the spleen parenchyma was embolized using polyvinyl alcohol particles (300-500 $\mu \mathrm{m}$ in diameter) until the flow was stagnated. Follow-up splenic artery injections showed that there was slow blood flow only to the part of the parenchyma that was not embolized (Figure 1) and the procedure was finalized. Computed tomography could not be performed before or after the intervention because the patient's serum creatinine level was $1.3 \mathrm{mg} \mathrm{dL}^{-1}$. Although only 40-50 mL of intravenous contrast material was used during the procedure, the serum creatinine level continued to increase post procedure.

Immediately following the angiographic procedure the patient's hemoglobin level was $3.8 \mathrm{~g} \mathrm{dL}^{-1}$; however, levels as low as $1.4 \mathrm{~g} \mathrm{dL}^{-1}$ were recorded 

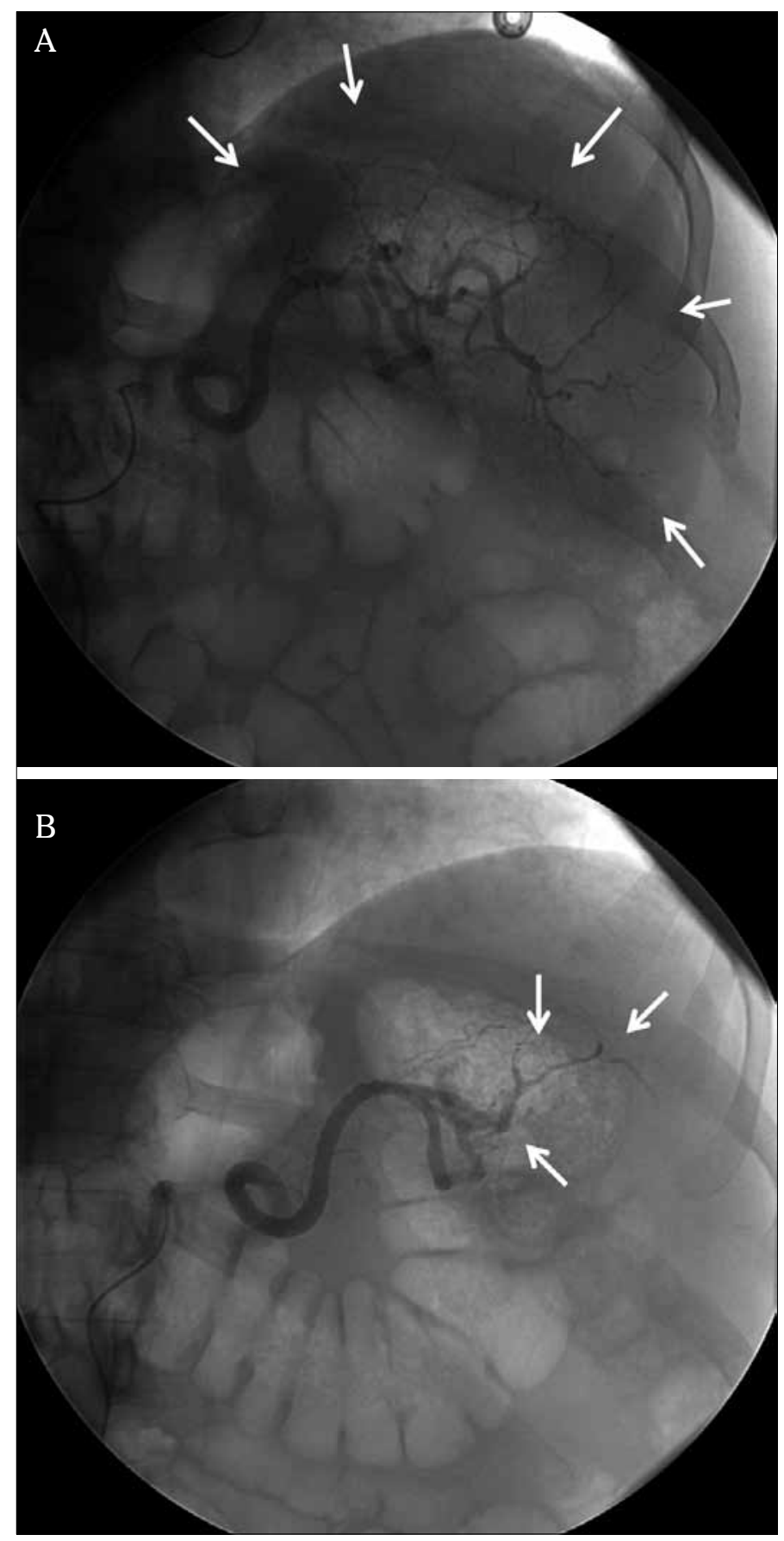

Figure 1. A significant decrease in splenic blood flow following splenic artery injections is observed

during the patient's hospitalization. One week post embolization the patient's hemoglobin level reached $6.0 \mathrm{~g} \mathrm{dL}^{-1}$ without transfusion. On the $15^{\text {th }}$ day of hospitalization a compatible erythrocyte suspension became available and the patient's hemoglobin level increased to $8.5 \mathrm{~g} \mathrm{dL}^{-1}$ after transfusion of 4 units. The patient underwent surgery on the $26^{\text {th }}$ day of hospitalization. Massive bleeding of $2.5 \mathrm{~L}$ occurred during splenectomy and hypovolemic shock ensued. The patient required intubation and mechanical ventilation, as well as hemodialysis because of acute renal failure. Septic shock and disseminated intravascular coagulation developed and the patient died on the $40^{\text {th }}$ day in the ICU-14 days following splenectomy.

Written informed consent was obtained from the patient's family.

\section{Discussion}

The presented case shows that splenic artery embolization can be performed successfully in patients that require splenectomy, but cannot undergo the procedure due to problematic hematological parameters and poor general health status. The indications for splenectomy and splenic artery embolization are variable. In traumatic injuries of the spleen minimal bleeding and maximal functional splenic tissue are sought. On the other hand, in patients with hypersplenism and autoimmune hemolysis the aim is to decrease the sequestration and destruction functions of the spleen while preserving its immune functions. Splenic artery embolization may be preferred over surgery when the aim is to preserve the immune functions of the spleen.

Splenic artery embolization was first described in the 1970s and has since been used in different clinical settings, including traumatic spleen rupture, portal hypertension-related ascites, immune thrombocytopenic purpura, hemoglobinopathies, and hereditary spherocytosis [1-5]. Use of splenic embolization in patients with autoimmune hemolytic anemia is rarely reported [6]. The procedure may fail in some patients if an adequate quantity of spleen parenchyma cannot be embolized or if autoimmune hemolysis is IgM mediated.

Significant bleeding is the most serious complication related to splenectomy. Preoperative splenic artery embolization has been suggested as a potential way to reduce this complication [7]. Embolization can decrease the need for transfusion in patients with immune thrombocytopenic purpura when performed prior to splenectomy [8]. Contrast-induced nephropathy is a potential adverse outcome of the embolization procedure, particularly in patients with such risk factors as chronic renal disease, diabetes mellitus, advancing age, congestive heart failure, hypotension, and shock. 
Partial splenic artery embolization was developed as a minimally invasive endovascular procedure in order to avoid complications due to hypersplenism and associated comorbidities [9,10]. Polyvinyl alcohol and gelatin particles are the most commonly used materials, They can reach the most distal points at the smallest arteriole level via blood flow and obliterate the arterioles. Use of small particles may result in unintended embolization of small arteries, including the pancreatic branches $[9,10]$.

Splenic artery embolization was used as an alternative treatment option in the presented case, which not only decreased the requirement for transfusion, but also offered a time period of relative wellbeing until surgery. The patient's decline began with major bleeding of $2.5 \mathrm{~L}$ during splenectomy, which resulted in hypovolemic shock and ultimately death. This raises the question of what would have happened if the patient had not undergone splenectomy, but was followed-up conservatively with splenic embolization only.

In conclusion, splenic artery embolization might be a valuable option for hemolytic anemia as a bridging therapy to surgery or as a stand-alone alternative therapy, especially in critically ill patients with disorders that contraindicate surgery.

\section{Conflict of interest statement}

The authors of this paper have no conflicts of interest, including specific financial interests, relationships, and/or affiliations relevant to the subject matter or materials included.

\section{References}

1. Raikhlin A, Baerlocher MO, Asch MR, Myers A. Imaging and transcatheter arterial embolization for traumatic splenic injuries: review of the literature. Can J Surg 2008;51:464-72.

2. N'Kontchou G, Seror O, Bourcier V, Mohand D, Ajavon Y, Castera L, Grando-Lemaire V, Ganne-Carrie N, Sellier N, Trinchet JC, Beaugrand M. Partial splenic embolization in patients with cirrhosis: efficacy, tolerance and longterm outcome in 32 patients. Eur J Gastroenterol Hepatol 2005;17:179-84. [CrossRef]

3. Pratl B, Benesch M, Lackner H, Portugaller HR, Pusswald B, Sovinz P, Schwinger W, Moser A, Urban C. Partial splenic embolization in children with hereditary spherocytosis. Eur J Haematol 2008;80:76-80.

4. Miyazaki $\mathrm{M}$, Itoh $\mathrm{H}$, Kaiho $\mathrm{T}$, Ohtawa $\mathrm{S}$, Ambiru $\mathrm{S}$, Hayashi S, Nakajima N, Oh H, Asai T, Iseki T. Partial splenic embolization for the treatment of chronic idiopathic thrombocytopenic purpura. AJR Am J Roentgenol 1994;163:123-6.

5. Meral A, Sevinir B, Sadikoğlu Y, Nacarküçük E, Günay U. Partial splenic embolization in beta-thalassemia major. A case report. Turk J Pediat 2000;42:76-9.

6. Campbell R, Marik PE. Severe autoimmune hemolytic anemia treated by paralysis, induced hypothermia and splenic embolization. Chest 2005;127:678-81. [CrossRef]

7. Totte E, Van Hee R, Kloeck I, Hendrickx L, Zachee P, Bracke P, Hermans P. Laparoscopic splenectomy after arterial embolization. Hepatogastroenterology 1998;45:773-6.

8. Baú PC, Cavazolla SA, Souza HP, Garicochea B. Preoperative embolization of the splenic artery in patients that underwent splenectomy for immune thrombocytopenic purpura. Acta Cir Brasil 2007;22:470-3. [CrossRef]

9. Wang HY, Shih SC, Lin SC, Chang WS, Wang TE, Lin FJ, Yang FS. Partial splenic embolization: 12-month hematological effects and complications. Hepatogastroenterology 2008;55:1838-42.

10. Yoshida H, Mamada Y, Taniai N, Tajiri T. Partial splenic embolization. Hepatol Res 2008;38:225-33. [CrossRef] 